\title{
EFFICIENCY OF TWO NOVEL BIOCONTROL COMPOUND AT LC50Ś AGAINST THE FOURTH LARVAL INSTAR OF BLACK CUTWORM, AGROTIS IPSILON (HUFNAGEL) (LEPIDOPTERA: NOCTUIDAE)
}

\author{
ABDEL-RAHIM, ELHAM F. AND HANAN F. ABDEL-HAFEZ
}

Sids Agric. Res. Station, Plant Protection Res. Institute, ARC, Giza, Egypt

(Manuscript received 2 October 2011)

\begin{abstract}
The efficiency of two novel compounds (takumi and radiant) and conventional insecticide (methomyl) against the fourth instar larvae of Agrotis ipsilon was evaluated under laboratory conditions through determination their LC50 values. Takumi was the most toxic one against the $4^{\text {th }}$ larvae treated by both feeding and dipping techniques showing $\mathrm{LC}_{50} \mathrm{~S}$ of 6 and $80 \mathrm{ppm}$, respectively. While, Radiant was the second one, the $\mathrm{LC}_{50} \mathrm{~S}$ were 28 and $500 \mathrm{ppm}$, respectively. Whereas, methomyl was the least one, its $\mathrm{LC}_{50} \mathrm{~S}$ were 187.5 and $900 \mathrm{ppm}$, respectively.

All the treated larvae were biologically affected by the three tested compounds. The effects were varied according to the applied method and compound. The larval treatments via leaf dip method had the highest effect in larval and pupal duration increase.Methomyl treatment induced the longest period in this respect, followed by takumi and radiant ones. Therefore, the treated larvae by this method were resulted in pupal malformation percent increase. While, the larval treatment via dip method had the strongest effect in shifting of sex ratio of males and females percent, decrease of pupation percent, pupal weight and adult longevity and increase of adult malformation percent. Also, the larval treatment of $4^{\text {th }}$ instars with takumi by both leaf and larval dip and the treatment with radiant via larval dip method had the strongest effect in adult fecundity reduction to reach zero, as compared to591.6 and 524.9 eggs/female of control of both methods, respectively.
\end{abstract}

\section{INTRODUCTION}

The black cutworm, A. ipsilon attacks the seedlings of most crops. Crops attacked include beans, broccoli, cabbage, carrot, Chinese broccoli, Chinese cabbage, Chinese spinach, corn, eggplant, flowering white cabbage, green beans, head cabbage, lettuce, mustard cabbage, potato, spinach, sugarcane, sweet potato, tomato, turnip, as well as many other plants (Rings et. al., 1975). They commonly feed on seedlings at ground level, cutting off the stem and sometimes dragging the plants into their burrows. Most of the plant is not consumed but merely eaten enough to cause it to topple. Since the larvae occur burrowed near the roots of the host, it sometimes feeds 
on roots and the below ground stem. Because of the nature of their feeding on young plants, this pest can do great damage in newly planted fields. The rising consumption of currently used insecticides in developing countries has led to a number of problems such as insect resistance, environmental pollution and the health hazards associated with pesticide residues .It is therefore necessary to complement our reliance on synthetic pesticides with less hazardous, safe, and biodegradable substitutes. Flubendiamide, a novel class insecticide possessing a unique chemical structure, a new, promising class of insecticides called 1, 2-benzenedicarboxamides or phthalic acid diamides, with exceptional activity against a broad spectrum of lepidopterous insects. It was discovered by Nihon Nohyaku Co., Ltd., and was registered in Japan in 2007 under the trade name of Phoenix WDG (Kintscher et. al., 2007 and Tohnishi et. al. 2010). Spinetoram is a new member of the spinosyn class of insect management tools developed by Dow Agrosciences Company. It is derived from fermentation of Saccharopolyspora spinosa as are other spinosyns, but fermentation is followed by chemical modification to create the unique active ingredient in spinetoram. In Egypt, Temerak (2007) used the spinosyn products, spinosad and spinetoram to combat egg masses of cotton leafworm; he indicated that Radiant SC12\% was 5 and 7 times stronger than spintor SC24\% in the field and laboratory. Thus, this product have an excellent activity against a wide range of lepidopterous pests on many field crops such as vegetables, fruits, tea, cotton, and rice (Hirooka et. al., 2007).It is applied at low rates and has low impact on most beneficial insects (Mertz and Yao, 1990). Pests controlled by spinetoram include beet army worm, Spodoptera exigua, thrips, Frankliniella spp., cabbage looper, Trichoplusia ni and codling moth, Cydia pomonella. It causes excitation of the insect nervous system by altering the function of nicotine and GABA-gated ion channels (Crouse and Sparks, 1998). The conventional insecticide, methomyl was used for the lepidopterous pests control (Kassem et. al., 1986).

The aim of the present study is to compare the insecticidal activity of the two novel compounds takumi and radiant as compared to the conventional insecticide methomyl against the fourth instar larvae of $A$. ipsilon

\section{MATERIALS AND METHODS}

\section{The laboratory strains.}

\section{1-Insect rearing:}

The fourth instar larvae $A$. ipsilon used in this experiment were separated by plastic grids to form individual chambers (ice cubes) to avoid a cannibalism phoneme and fed on fresh castor leaves, Ricinus communis, they were incubated at $25 \dot{C}, 60-70 \%$ R.H. in the laboratory according to Abdel-salam (1980) until the pupation. The newly 
emerged moths were mated within the large glass jars provided with a cotton piece soaked in $10 \%$ sugar solution as a feeding source and muslins as ovipostion site for the moths. The fourth instar larvae were used for the bioassay test.

\section{2-Materials used:}

Common name: Takumi

Chemical name: Flubendiamide

Molecular formula: $\mathrm{C}_{23} \mathrm{H}_{22} \mathrm{~F}_{7} \mathrm{IN}_{2} \mathrm{O}_{4} \mathrm{~S}$<smiles>Cc1cc(C(C)C)ccc1NC(=O)c1cccc(I)c1C(=O)NC(C)(C)CS(C)(=O)=O</smiles>

\section{2-Radiant}

Common name: Radiant

Chemical name: Spinetoram (XDE-175-J)

Spinetoram is the second generation of the spinosyn group. It is a trademark of Dow AgroSciences. Spinetoram is prepared from a mixture of two natural spinosyns, spinosyns J and L produced by S. spinosa.

Major component (3'-ethoxy-5, 6-dihyro spinosyn J).

Minor component (3'-ethoxy spinosyn $L$ ). 
Molecular formula: $\mathrm{C} 43 \mathrm{H} 69 \mathrm{NO} 10$ and $\mathrm{C} 42 \mathrm{H} 69 \mathrm{NO} 10$

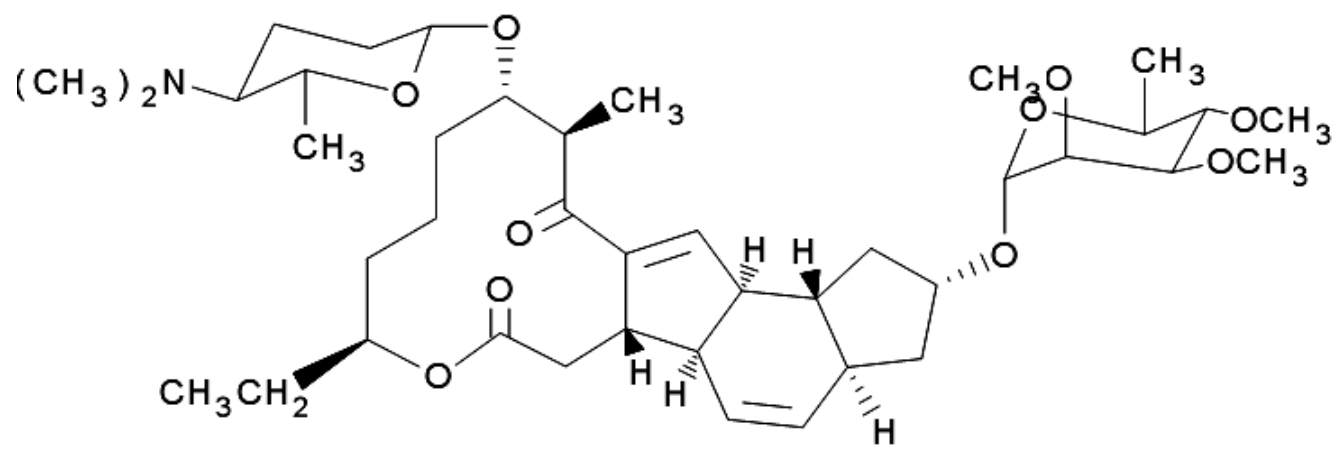

\section{spinosyn $A$}

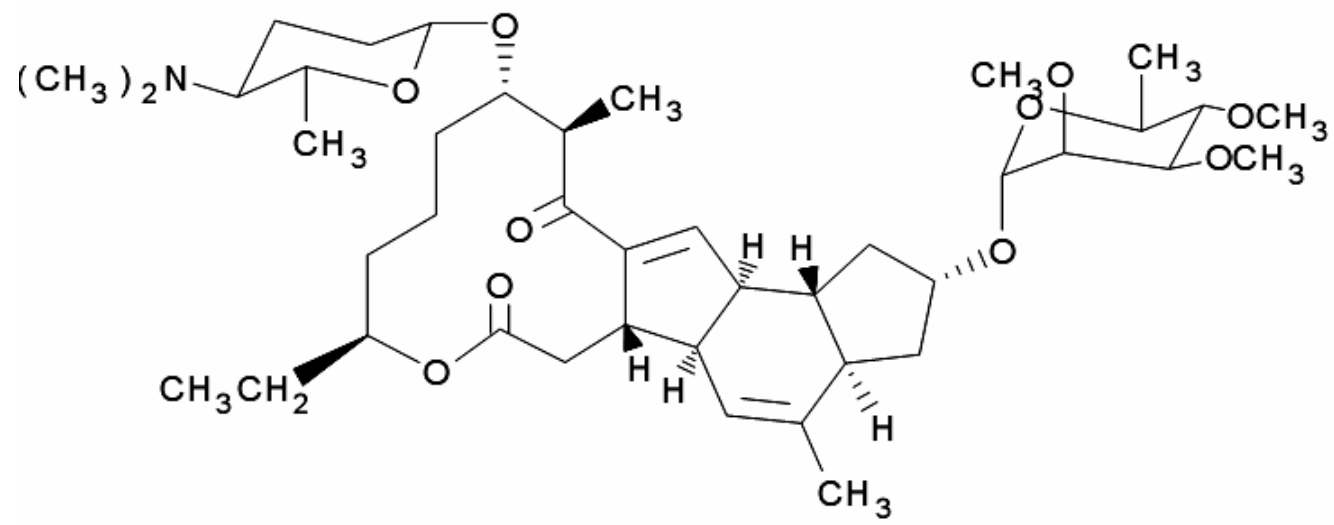

\section{spinosyn D}

2.3- Methomyl (90\%) k.z.

Common name: Methomyl

Chemical name: thioacetimidate methyl $\mathrm{N}$ (methylcarbamoyloxy)

Molecular formula: $\mathrm{C} 5 \mathrm{H} 10 \mathrm{~N} 2 \mathrm{O} 2 \mathrm{~S}$ 


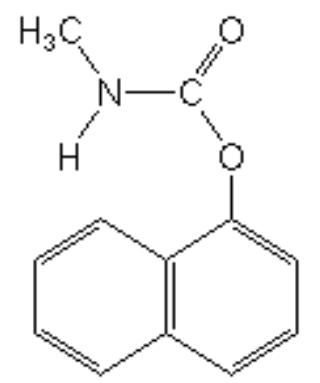

\section{3- Test procedures}

\section{A-feeding method:}

Castor leaves were dipped in solutions of the three tested compounds (takum, radiant ant methomyl) for 15 seconds at different concentrations and the leaves left to dry in air current for about $1 \mathrm{hr}$ before larval feeding .All concentrations were prepared on the active ingredient basis (p. p. m). Takumi was tested at 31.25, 15.6, 7.8, 3.9, 1.95 p.p.m.The radiant was tested at $250,125,62.5,31.3,15.6,7.8 \mathrm{ppm}$. While, methomyl was tested at 750, 375, 187, 93.7 46.9p.p.m. Also, the castor leaves were dipped in only distilled water and used as control. About thirty larvae of three replicates of the fourth instar fed on the treated leaves were placed individually within the rearing chambers and also for the control. After $24 \mathrm{~h}$ the treated leaves were replaced by other untreated ones and the larvae were continued fed until the pupation.

\section{B-dipping method:}

The larvae of the fourth instar were gently dipped into insecticide solutions of the three tested compounds with a dip net for 5seconds to ensure complete wetting, then the treated larvae were then poured through fine muslin suspended over an empty beaker and left for drying for 10 minutes, then after the treated larvae were then transferred individually within rearing chambers to fed on untreated castor leaves (Shinde et. al., 2011) until the pupation.Takumi was tested at 250, 125, 62.5, 31.3, $15.6 \mathrm{ppm}$, Radiant was tested at 2000,1000,500,250,125, 62.5ppm and methomyl was tested at $1500,750,375,187 \mathrm{ppm}$. Whereas those of the controls were dipped in distilled water and fed untreated castor leaves until the pupation. Thirty larvae of three replicates were used in treatment and control. 
The chambers were examined daily to determine the larval mortality exposed for the tested insecticides via feeding or dipping methods. The different biological effects such larval and pupal duration, pupation and adults emergence percentage, pupal weight ,adult fecundity ,fertility ,longevity , sex ratio were determined at the LC50 values of the three compounds. Also, the observed malformations were recorded and photographed.

\section{4-Statistical analysis :}

The total percent of the larval mortality of the three tested compounds was recorded after 24 hour of the larval treatment of $4^{\text {th }}$ instar via leaf dip or larval dip and the data corrected according to Abbott formula (Abbott, 1925). The data were then analyzed using the probit analysis (Finney, 1971) and the LC50 values of the three tested compounds were estimated. The different biological effects were estimated at the LC50 values. The obtained data of the biology were statistically calculated through Excel for windows computer program to determine the F-value, P-value and L.S.D (least significant difference) at 0.05 or 0.01 level.

\section{RESULTS AND DISCUSSION}

\section{1-Insecticidal activity:}

Data in Table (1) showed the toxic effects of the three tested compounds, takumi, radiant and methomyl against the $4^{\text {th }}$ instar larvae of $A$.ipsilon treated by the feeding and dipping methods. Takumi was the most toxic one against the $4^{\text {th }}$ instar larvae treated with the two mentioned methods. The $\mathrm{LC}_{50}$ values were 6 and $80 \mathrm{ppm}$ for the larvae treated via leaf or larval dip methods, respectively .While, Radiant was the next one, the $\mathrm{LC}_{50}$ values were 28 and 500 ppm, respectively. Whereas, methomyl was the least effective, its $\mathrm{LC}_{50}$ values were 187.5 and $900 \mathrm{ppm}$ for larvae treated to by the two methods, respectively.

Table 1. Insecticidal activity of Takumi, Radiant and Methomyl expressed as LC50 values against the $4^{\text {th }}$ instar larvae of $A$. ipsilon.

\begin{tabular}{|c|c|c|c|c|c|c|c|c|}
\hline \multirow{4}{*}{ Treatment } & \multicolumn{8}{|c|}{ Method of treatment } \\
\hline & \multicolumn{4}{|c|}{ feeding } & \multicolumn{4}{|c|}{ dipping } \\
\hline & \multirow{2}{*}{$\begin{array}{l}\text { LC50 } \\
\text { values } \\
\text { P.p.m }\end{array}$} & \multirow[t]{2}{*}{$\begin{array}{c}\text { Slope } \\
\text { function }\end{array}$} & \multicolumn{2}{|c|}{$\begin{array}{c}95 \% \text { confidence } \\
\text { limit }\end{array}$} & \multirow{2}{*}{$\begin{array}{l}\text { LC50 } \\
\text { values } \\
\text { P.p.m. }\end{array}$} & \multirow[t]{2}{*}{$\begin{array}{c}\text { Slope } \\
\text { function }\end{array}$} & \multicolumn{2}{|c|}{$\begin{array}{c}95 \% \\
\text { confidence limit }\end{array}$} \\
\hline & & & Upper & Lower & & & Upper & Lower \\
\hline Takumi & 6 & 3.33 & 14.4 & 2.5 & 80 & 6.10 & 208 & 30.8 \\
\hline Radiant & 28 & 9.59 & 89.6 & 8.75 & 500 & 9 & 1600 & 156.3 \\
\hline Methomyl & 187.5 & 6.4 & 562.5 & 62.5 & 900 & 6.6 & 2700 & 300 \\
\hline
\end{tabular}


These results are in agreement with those obtained by Shinde et. al. (2011) who showed the toxicity of Spinter, Cypermethrin and Karate after48hours of treatment of $2^{\text {nd }}$ instar of Helicoverpa armigera by larval dip bioassay. They found that the Karate was highest with LC50 of 70.31ppm followed by Cypermethrin with LC50 277.67ppm and Spinter 454.85ppm. Also, Hassan (2009) estimated the LC50 of the second instar larvae of $S$. littoralis treated with spinetoram for 48hour ranged from 0.022 to $0.033 \mathrm{ppm}$. And it ranged from 1.78 to $2.64 \mathrm{ppm}$ of the $4^{\text {th }}$ instar treated with spinetoram. Hamouda and Dahi (2008) indicated that spinetoram is a fairly toxic with LC50 (1.11 ppm) when tested against the $4^{\text {th }}$ instar of S. littoralis. While, Elbark et. al. (2008) reported that the LC ${ }_{50}$ of the $2^{\text {nd }}$ and $4^{\text {th }}$ larval instars of $S$. littoralis treated with radiant after 24 hour were 0.05 and $6.67 \mathrm{ppm}$, respectively.

\section{Latent biological effect:}

\subsection{Larval and pupal periods:}

Data in Table (2) indicated that the larval treatment of the $4^{\text {th }}$ instar of A.ipsilon with takumi, radiant and methomyl at $\mathrm{LC}_{50}$ values highly and significantly $(p<0.01)$ increased the larval duration. The larvae treated via leaf dip method had pronounced effect ( $p$ <0006). Methomyl treatment induced the longest duration period of larvae i.e. averaged 21.3days, as compared to14.6days of control. While the takumi and radiant treatment increased the larval duration to average 16.8 and16.5days, respectively. Also, the $4^{\text {th }}$ instars treated with the takumi, radiant and methomyl via larval dip method induced significant $(p<0.00001)$ increase in the larval duration .Both radiant and methomyl treatments gave the longest duration, it averaged 22 and 20.6days, as compared to15.6days of control. While takumi treatment increased the larval period to average19.9days, as compared to that of control (15.6days).

Likewise, the treatment of the fourth instars larvae of A.ipsilon with the three tested compounds at $\mathrm{LC}_{50}$ values highly and significantly $(\mathrm{p}<0.01)$ increased the pupal duration. Leaf dip method had pronounced effect $(p<0.002)$. Methomyl induced the longest pupal period averaged15.2days, as compared to10.4days of control. While, the takumi and radiant treatments increased the pupal duration to average13.1 and12.4days, respectively.On the other hand, larval dip method induced significant ( $p$ $<0.00096$ ) increase in the pupal duration. Both takumi and methomyl treatments gave the longest period of larval duration, it averaged 16days, as compared to 11.6days of control. While, the radiant treatment induced the pupal period increase, it averaged 14.4days.

These results agree with that obtained that El-Barkey et. al. (2009) who showed a prolongation in larval and pupal developments resulted from eggs of Pectinophora gossypiella at one, two and prehatching days old treated by Radiant, estimated by $20 . .8,18.5$ and 8.2 days, respectively for larvae and $8.9,8.8$ and 7.9 days for pupae. 
Table 2. Biological activities of takumi, radiant and methomyl at their LC50 values against the $4^{\text {th }}$ instar larvae of $A$. ipsilon.

\begin{tabular}{|c|c|c|c|c|c|c|c|c|}
\hline \multirow[t]{2}{*}{ Treatment } & \multirow[t]{2}{*}{ Method } & \multirow{2}{*}{$\begin{array}{c}\text { Larval } \\
\text { duration } \\
\text { (days) } \pm \\
\text { SD }\end{array}$} & \multicolumn{2}{|c|}{ Pupation\% } & \multirow{2}{*}{$\begin{array}{c}\text { Pupal } \\
\text { duration } \\
\text { (days) } \pm \\
\text { SD }\end{array}$} & \multirow{2}{*}{$\begin{array}{c}\text { Pupal } \\
\text { weight } \\
\text { (mg) } \\
\pm \text { S.D }\end{array}$} & \multicolumn{2}{|c|}{$\begin{array}{l}\text { Adult } \% \\
\text { emergence } \pm \text { S.D }\end{array}$} \\
\hline & & & $\begin{array}{l}\text { Normal } \\
\text { Mean } \pm \text { SD }\end{array}$ & Malfo & & & Normal & $\begin{array}{c}\text { Malfo } \\
\%\end{array}$ \\
\hline \multirow[t]{2}{*}{ Takumi } & feeding & $16.8+1 * *$ & $60 \pm 10 * *$ & 0 & $13.1 \pm 1 * *$ & $450 \pm 14 *$ & $84 \pm 1.4 *$ & 14 \\
\hline & dipping & $\begin{array}{l}19.9 \pm 3.1^{*} \\
*\end{array}$ & $55 \pm 15^{* *}$ & 19.7 & $16 \pm .5^{* *}$ & $371 \pm 164 * *$ & $86 \pm .7 *$ & 23 \\
\hline \multirow[t]{2}{*}{ Radiant } & feeding & $16.5 \pm 2 . * *$ & $55 \pm 5^{* *}$ & 0 & $\begin{array}{c}12.4 \pm 1.2 * \\
*\end{array}$ & $407 \pm 45 *$ & $82.2 \pm 2 *$ & 18.5 \\
\hline & dipping & $22 \pm 2.7^{* *}$ & $50 \pm 10 * *$ & 12.5 & $\begin{array}{c}14.4 \pm 1.5^{*} \\
*\end{array}$ & $404 \pm 54 * *$ & $41.5 \pm 5^{* *}$ & 0 \\
\hline \multirow[t]{2}{*}{ Methomyl } & feeding & $21.3 \pm 3^{* *}$ & $45 \pm 15^{* *}$ & 33.3 & $\begin{array}{l}15.2 \pm 0.8^{*} \\
*\end{array}$ & $418 \pm 53 *$ & $66.4 \pm .5 * *$ & 0 \\
\hline & dipping & $20.6 \pm 2 * *$ & $40 \pm 10 * *$ & 0 & $\begin{array}{l}15.8 \pm 0.5^{*} \\
*\end{array}$ & $310 \pm 22 * *$ & $90 \pm 0.7^{*}$ & 7.2 \\
\hline \multirow[t]{2}{*}{ Control } & feeding & $14.6+2$ & 100 & 0 & $10.4 \underline{+1.1}$ & $518+28$ & 100 & 0 \\
\hline & dipping & $15.6 \pm 2$ & 100 & 0 & $11.6 \pm 1$ & $494+31$ & 100 & 0 \\
\hline \multirow[t]{2}{*}{$F$ value } & feeding & 37.9 & 5473.6 & & 8.18 & 13.9 & 988.95 & \\
\hline & dipping & 60.1 & 2567.5 & & 67.13 & 26.4 & 16651.8 & \\
\hline \multirow[t]{2}{*}{$P$ value } & feeding & 0.00062 & 0.00144 & & 0.00207 & 0.0035 & 0.0268 & \\
\hline & dipping & 0.000014 & 0.00566 & & 0.00096 & 0.0159 & 0.0275 & \\
\hline \multirow[t]{2}{*}{ L.S.D.at.05 } & feeding & 1.2 & 3.5 & & 1.1 & 61.6 & 2.4 & \\
\hline & dipping & 1.6 & 9 & & 1.1 & 64.3 & 4.9 & \\
\hline \multirow[t]{2}{*}{ L.S.D.at.01 } & feeding & 1.5 & 6.5 & & 1.6 & 102.1 & 5.5 & \\
\hline & dipping & 2 & 16.5 & & 1.6 & 106.7 & 11.2 & \\
\hline
\end{tabular}

.** = Highly Significant $(\mathrm{p}<0.01)$

S.D. =Standard deviation

L.S.D. = Least significant difference

n. $s=$ none Significant $(p>0.05)$

\author{
* Significant $(p<0.05)$ \\ Malfo. $=$ Malformation $\%$ \\ Lab. =Laboratory strain
}

\subsection{Pupation and adult emergence:}

Data in Table (2) demonstrated that the three tested compounds, takumi, radiant, and methomyl at their LC50s, caused highly significant $(p<0.01)$ reduction of the pupation percent of $A$. ipsilon, as compared to control. Larval dip method had pronounced effect $(0.00566)$. The pupation ranged from $40-55 \%$, as compared to that of the check (100\%).Also the treatment of the fourth instar larvae via leaf dip caused highly significant $(p<0.00144)$ decrease in the pupation ranged $45-60 \%$, as compared to control (100\%).

Data in Table (2) showed that larval dip technique caused highly and significant $(p<0.01)$ reduction in the adult emergence to average $41.5 \%$, as compared to that of the control $(100 \%)$. Larval treatment with methomyl by leaf dip highly and significantly $(p<0.01)$ decreased the adult emergence to average66. $4 \%$, as compared 
to control. While the treatment of the fourth instar larvae of $A$. ipsilon either takumi by leaf and larval dip or radiant via leaf dip method and metomyl by larval dip method at their LC50s, significantly $(p<0.05)$ reduced the adult emergence percentages to range $84-86$ and $82.2-90 \%$ as compared to $100 \%$ of the check.

These results are in agreement with those obtained by Ahmed (2004) who found that the average percentage of pupations and adult emergence for pink and spiny bollworms gradually decreased with increasing concentrations of the tested compounds (Agerin, Diple 2x Naturalis $L$, Spinosad) in laboratory and field strains.

\subsection{The Pupal weight:}

Data in Tables (2) demonstrated that larval dip caused highly significant $(p<0.01)$ reduction on the weight of the resulting pupae to average 371,404 and $310 \mathrm{mg}$,repectively, as compared to $494 \mathrm{mg}$ of control. While, the leaf dip caused significant ( $p<0.0035$ ) decrease in the pupal weight to average 450,407 and $418 \mathrm{mg}$, respectively, as compared to $518 \mathrm{mg}$ of control.

These results are in accordance similar with those obtained by Ahmed (2004).

\subsection{Malformation effects:}

Data in Table (2) showed that the larval treatment of $4^{\text {th }}$ instars of $A$. ipsilon with methomyl by the leaf dip method at the LC50s induced the highest percent of pupal malformation, it reached $33.3 \%$, as compared to $0 \%$ of control. Also, the larval treatment with takumi and radiant via the larval dip method induced a noticeable increase in the pupal malformations reached 19.7 and $12.5 \%$, as compared to control.

With regard to the adult malformations (Table, 2), it was found that the larval treatment of $4^{\text {th }}$ instar of $A$. ipsilon at the LC50s values with takumi by larval dip and radiant by leaf dip method induced the greatest percent of adult malformations reached 23 and $18.5 \%$, respectively, as compared to $0 \%$ of control. While the larval treatment with takumi by leaf dip and methomyl via larval dip method induced malformation of 14 and $7.5 \%$, as compared to control (0\%).

These results are in harmony to those obtained by Ahmed (2004) who reported that Spinosad gave malformed pupal and adults in both laboratory and field strains of both Pink and Spiny bollworms. 
EFFICIENCY OF TWO NOVEL BIOCONTROL COMPOUND AT LC50Ś AGAINST

THE FOURTH LARVAL INSTAR OF BLACK CUTWORM,

AGROTIS IPSILON (HUFNAGEL) (LEPIDOPTERA: NOCTUIDAE)

fig 
Malformations of $A$. ipsilon pupae resulting from the larval treatment of $4^{\text {th }}$ instars with takumi by larval dip method appeared as larval-pupal intermediates with larval cuticle patches, head capsule and thoracic legs, posterior half of the body has the pupal properties (fig.1,2) .While, the moth malformations produced from larvae treated with takumi by leaf and larval dip method appeared as moths with complete absent one of both wings(fig.3) or moths with slight twisted wings and weakly developed body(fig.4) or moths with slight twisted wings(fig.5). Malformations of pupae resulting from the larval treatment of the $4^{\text {th }}$ instars with radiant by larval dip method showed as larval-pupal intermediates (fig.6) or pupae maintain with old moulting skin in the posterior end of the body (fig.7). Malformations of adults resulting from the larval treatment of $4^{\text {th }}$ instar with radiant by leaf dip method appeared as adult malformations often appeared as a moth failed to emerge from the pupal skin at head and thorax (fig.8) or moths with deformed twisted wings and weakly developed body (fig.9, 10). Malformations of pupae resulting from the larval treatment of $4^{\text {th }}$ instars with methomyl by leaf dip method appeared as monstrosital pupae (fig.11) or undersized pupae (fig.12).And malformations of adults resulting from the larval treatment of $4^{\text {th }}$ instars with methomyl by larval dip method appeared as moths with deformed twisted wings and weakly developed body (fig.13)as compared to normal pupae and adults of control(fig.14 and 15).

\subsection{Adult fecundity and fertility:}

Data in Table (3) indicated that $4^{\text {th }}$ instar larvae of $A$. ipsilon treated with takumi at the LC50s either by leaf or larval dip methods and also the larval treatment of the same instar with radiant by larval dip method had the strongest effect in adult fecundity reduction to reach zero, as compared to592 and 525 eggs/f of untreated larvae exposed for leaf and larval dip methods, respectively. While the larval treatment of the $4^{\text {th }}$ instar with radiant via leaf dip method and the treatment with methomyl by leaf and larval dip methods highly significant $(p<0.01)$ decreased the adult fecundity to average 25,93 and 70 eggs/f ,respectively, as compared to that of control. 
Table 3. Biological activities of Takumi, Radiant and methomyl against the adults treated as $4^{\text {th }}$ instar larvae of $A$. ipsilon with the $\mathrm{LC}_{50}$ values.

\begin{tabular}{|c|c|c|c|c|c|c|}
\hline \multirow[t]{2}{*}{ Treatments } & \multirow[t]{2}{*}{ Method } & \multirow{2}{*}{$\begin{array}{c}\text { Fecundity } \\
\text { Mean+S.D. } \\
\text { (eggs/f) }\end{array}$} & \multirow[t]{2}{*}{$\begin{array}{c}\text { Hatching } \\
\%\end{array}$} & \multirow{2}{*}{$\begin{array}{l}\text { Longevity } \\
\text { Mean+S.D } \\
\text { (days) }\end{array}$} & \multicolumn{2}{|c|}{$\begin{array}{c}\text { Adult sex ratio } \\
(\%) \\
\end{array}$} \\
\hline & & & & & Male & Female \\
\hline \multirow[t]{2}{*}{ Takumi } & feeding & $0 \pm 0 * *$ & 0 & $5 \pm 0.4 * *$ & 50 & 50 \\
\hline & dipping & $0 \pm 0 * *$ & 0 & $6.5 \pm 0.9 * *$ & 75 & 25 \\
\hline \multirow[t]{2}{*}{ Radiant } & feeding & $25 \pm 5^{* *}$ & 100 & $5.9 \pm 1.3^{* *}$ & 54.6 & 45.5 \\
\hline & dipping & $0+0 * *$ & 0 & $6.1+1 * *$ & 75 & 25 \\
\hline \multirow[t]{2}{*}{ Methomyl } & feeding & $93 \pm 7.5^{* *}$ & 78.4 & $6.2 \pm 1.2^{* *}$ & 50 & 50 \\
\hline & dipping & $70 \pm 5^{* *}$ & 85.7 & $6.7 \pm 1.3 * *$ & 50 & 50 \\
\hline \multirow[t]{2}{*}{ Control } & feeding & $591.6+240$ & 100 & $9.8+2.7$ & 50 & 50 \\
\hline & dipping & $524.9+228$ & 100 & $8.6+1.8$ & \multirow[t]{9}{*}{40} & \multirow[t]{9}{*}{60} \\
\hline \multirow[t]{2}{*}{$F$ value } & feeding & 259.3 & & 36.6 & & \\
\hline & dipping & 1015 & & 22.5 & & \\
\hline \multirow[t]{2}{*}{$P$ value } & feeding & 0.00814 & & 0.0000171 & & \\
\hline & dipping & 0.00271 & & 0.000388 & & \\
\hline \multirow[t]{2}{*}{ L.S.D.at.05 } & feeding & 195.3 & & 1.4 & & \\
\hline & dipping & 93.5 & & 0.97 & & \\
\hline \multirow[t]{2}{*}{ L.S.D.at.01 } & feeding & 450.5 & & 2 & & \\
\hline & dipping & 215.7 & & 1.3 & & \\
\hline
\end{tabular}

$* *$ Highly Significant $(\mathrm{p}<0.01)$

$=$ Standard deviation

L.S.D. $=$ Least significant difference

n. $s=$ none Significant $(p>0.05)$
* Significant $(p<0.05)$ S.D.

Malfo. = Malformation $\%$

Likewise, the $4^{\text {th }}$ instar larvae of $A$. ipsilon treated with takumi at the LC50s either by leaf or larval dip methods and also the larval treatment of the same instar with radiant by larval dip method had the highest effect in eggs hatching percent to reach zero, as compared to $100 \%$ of control. While the larval treatment of $4^{\text {th }}$ instar with methomyl by leaf and larval dip method decreased the eggs hatching to78.4 and $85.7 \%$, respectively, as compared to that of the check. 
These results are in agreement with those obtained by Pineda et. al. (2007) who reported that Spinosad and methoxyfenozide reduced in a dose-dependent manner the fecundity and fertility of $S$. littoralis adult when treated oral and residually. Also, Ahmed (2004) mentioned that the number of eggs produced by spiny bollworm females resulting from the treated larvae with the Spinosad for laboratory and field strains larvae was decreased per female as compared with the control. Also, El-Barkey et. al. (2009) demonstrated a high reduction in the total eggs laid, percentage of hatchability of Pectinophora gossypiella eggs treated by Radiant.

\subsection{Adult longevity:}

Data in Table (3) showed that the treatment of the fourth instar of $A$. ipsilon with takumi, radiant and methomyl at the LC50s by larval dip had the most potent in significant decrease $(p<0.0004)$ of adult longevity to average $6.5,6.1$ and 6.7 days, as compared to8.6days of control. Also, the $4^{\text {th }}$ instar larvae treated with the three compounds by leaf dip method significantly decreased $(p<0.00002)$ the adult longevity to average5, 5.9 and 6.2 days, respectively, as compared to 9.8 days of control.

These results are in agreement with that obtained by El-Barkey et. al. (2009) who indicated a high reduction in adult longevity of Pectinophora gossypiella resulted from eggs at one, two and prehatching days old treated by Radiant.

\subsection{Adult sex ratio:}

Data in Table (3) demonstrated that the larval treatment of the fourth instar of $A$. ipsilon with the three tested compounds at their LC50s by larval dip method had the strongest effect in the sex ratio shifting of adult males and females. The larval treatment with both takumi and radiant compounds had pronounced effect, it induced males increase and females decrease in respect to that of control, it reached $75: 25 \%$ of adult males: females, respectively, as compared to $40: 60 \%$, respectively of control.Also, the larval treatment with methomyl induced males increase and females decrease to reach $50: 50 \%$, respectively, as compared to that of control $(40: 60 \%$, respectively).On other side, the larval treatment of $4^{\text {th }}$ instar with takumi and methomyl via leaf dip method had not effect on the sex ratio of males and females, it was recorded the same percentage of the check, it was 50:50\% adult males: females, respectively. While, the larval treatment of $4^{\text {th }}$ instar with radiant via leaf dip method induced males increase and females decrease to reach $54.6: 45.5 \%$ adult males: females, respectively, as compared to $50: 50 \%$ adult males: females, respectively of control. 


\subsection{Conclusion:}

The results of the present work demonstrated that the three tested compounds were effective against the survival of the $4^{\text {th }}$ instar larvae of A.ipsilon via leaf and larval dip method.Takumi had the highest efficacy against the insect, while radiant came next against the studied insect biology. Both takumi and radiant had defected of sex ratio of males and females in relative to control, hence, it affect on fecundity and eggs hatching \%. These compounds could achieve if applied their effects at the lethal concentrations within the integrate control program within the poison baits of this pest. Spinetoram has a neurotoxic effect manifested as well defined histopathologiacal changes in nerve and neurosecretory cells of $S$. littoralis (Hamouda and Dahi, 2008).Also, Flubendiamide-treated insects showed unique symptoms of poisoning resulting in complete and irreversible contraction paralysis led to the larvae death after few days when it injected within the Spodoptera frugiperda larvae Ebbinghaus et. al. $(2007, a, b)$.

\section{REFERENCES}

1. Abbott, W.S. 1925. A method of computing the effectiveness of an insecticide .J.Econ.Entomol. 18: 265-267.

2. Abdel-Salam, N. 1980. Ecological studies on genus of Agrotis.M.Sc.Thesis, Fac. Agriculture, Ain shams Univ.

3. Ahmed, E. 2004. New approaches for control of cotton bollworms. Ph.D. thesis, Faculty of Agric., Cairo Univ.

4. Crouse, G.D. and T.C. Sparks. 1998. Naturally derived materials as products lead for insects control: the spinosyns .Rev. Toxicol., 2: 133-146.

5. Ebbinghaus, U.K., P. Lümmen, k. Raming, T. Masaki and N. Yasokawa 2007a. Flubendiamide, the first insecticide with a novel mode of action on insect ryanodine receptors. Pflanzenschutz-Nachrichten, Bayer 60, (2): 117-140

6. Ebbinghaus, D., H. J. Schnorbach and A. Elbert: Field. 2007b. development of flubendiamide (Belt, Fame, Fenos, Amoli - a new insecticide for the control of lepidopterous pests Pflanzenschutz-Nachrichten 60, (2): 219-246

7. Elbark N. M., H. F. Dahi and Y. A. El-Sayed. 2008. Toxicicological evaluation and biochemical impacts for radiant as a new generation of spinosyn on Spodoptera littoralis larvae. Egypt. Acad. J. biolog. Sci., 1(2): 85 - 97.

8. El-Barkey1, N.M., A. E. Amer and A.K.Mervet. 2009. Ovicidal Activity and Biological Effects of Radiant and Hexaflumuron against eggs of Pink Bollworm, Pectinophora gossypiella .Egypt. Acad. J. biolog. Sci., 2(1): $23-36$ 
9. Finney, D.J. 1971. probit analysis ,3rd. edition, Cambridge Univ.Press, pp.333.

10. Hamouda, L.S. and H.F., Dahi. 2008. Neurotoxin effect of spinetoram on Spodoptera littoralis (Boisd.): Larvae. Egypt. Acad. J. biolog. Sci., 1 (2) 27 - 36.

11. Hassan, H.A. 2009. Efficiency of some new insecticides on physiological, histological and molecular level of cotton leafworm Egypt. Acad. J. biolog. Sci., 2 (2): 197- 209.

12. Hirooka, T., H.Kodama, K. Kuriyama and T. Nishimatsu. 2007. Field development of flubendiamide (Phoenix $\AA$, Takumi $\circledast$ ) for lepidopterous insect control on vegetables, fruits, tea, cotton and rice. Pflanzenschutz-Nachrichten, Bayer 60, 2

13. Kassem, S. M. I., M. I., Aly, N. S. Bakry and, M. I. Zeid. 1986. Efficacy of methomyl and its mixtures against the Egyption cotton leafworm and bollworms. Alexandria .journal. research, 31:3,291-300; 19 refs

14. Kintscher, U. E., P. Lümmen, K. Raming, T. Masaki and N. Yasokawa. 2007. Flubendiamide, the first insecticide with a novel mode of action on insect ryanodine receptors. Pflanzenschutz-Nachrichten, Bayer 60, 2.

15. Mertz, F. P. and R. C.Yao. 1990. Sacharo polyspora spinosa sp. Nov. isolated from soil collected in sugar mill rum still. Int. J. Sys. Bacteriol. , 40: 34-39.

16. Pineda , S., M. I. Schneider, G. Smagghe, A. M. Martínez, P. D. Estal, E. Viñuela, J. Valle and F. Budia. 2007. Lethal and sublethal effects of methoxyfenozide and spinosad on Spodoptera littoralis (Lepidoptera: Noctuidae). J Econ Entomol., 100 (3):773-80.

17. Rings, R.W., F.J. Arnold and B.A. Johnson. 1975. Host Range of the Black Cutworm on Vegetables: A Bibliography. Bull. Entomol. Soc. Am. 21(4):229-234.

18. Shinde, S.S., V.N. Kamtikar, S. Muley and R.K.Nimbalka. 2011. LC50 for insecticides against second instar larvae of Cotton bollworm Helicoverpa armigera in Maharashtra. J. Ecobiotech. 3(2): 22-24.

19. Temerak, S. A. 2007. Susceptibility of Spodoptera littoralis to old and new generation of spinosyn products in five cotton Governorates in Egypt. Resistance Pest Management Newsletter, 16 (2): 18-21.

20. Hirooka , T., K. Motoba , T. Nishimatsu , M. Tohnishi and A. Seo. 2010. Development of a Novel Insecticide, Flubendiamide). J. Pesticide Sci., 35, (4): 490-491 


\section{كفاءة اثثين من المركبات الحيوية عند قيم التركيز النصفي ضد يرقات العمر الرابع للاودة القارضة}

\section{الهام فاروق محمود عبد الرحيم وحنان فاروق السيد عبد الحفيظ}

معهز بحوث وقاية النباتات ـ مركز البحوث الزراعية الدقي . الجيزة ـ مصر

أجريت هذه الدر اسة بغرض مقارنة كفاءة أثنين من المركبات الحيوية ألحديثه وهى التاكومى

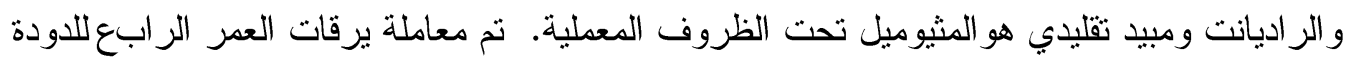
القارضة بالمبيدات بطريقتين تغذية اليرقات لمدة 24 ساعة على أور اق خروع نم غمره لمدة 15 1انية

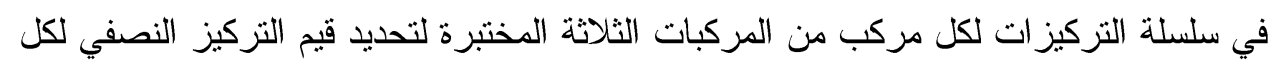
مركب أو عن طريق تغطبس اليرقات لمدة 5ثو انى في نركيزات محاليل المركبات الثلاثة المختبرة .

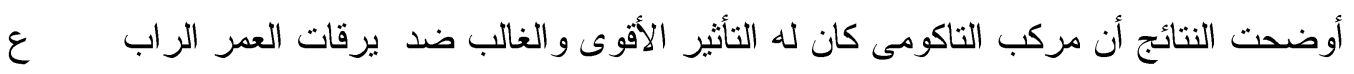

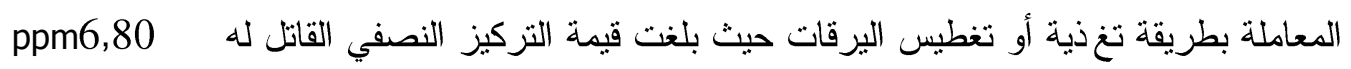
للعمر الر ابع المعامل بالطريقتين على التو الي وجاء مركب الراديانت بعد التاكومى حيث بلغ بلغ التركيز

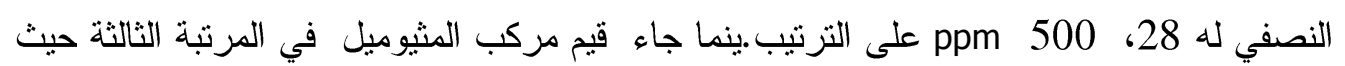

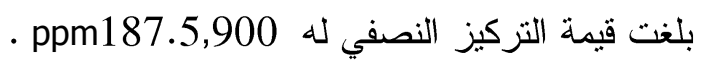

تأثرت المعايير البيولوجية لليرقات المعاملة مع اختلاف الطريقة والمركب المختبر .التغذية

على المركبات الثلاثة أحدثت التأثير الأقوى في زيادة العمر اليرقى و العذري و كان الثأثير أكثر

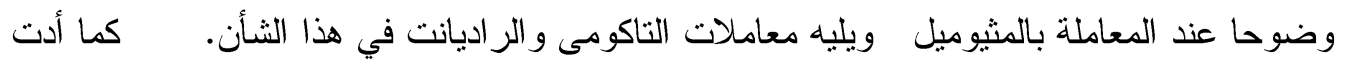

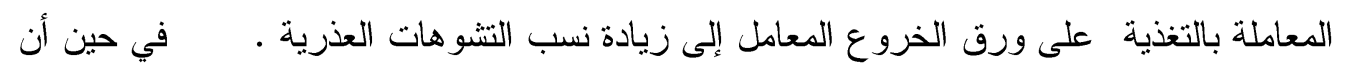
تغطيس اليرقات أعطى تأثير اقوي في تغير النسب الجنسية للذكور و الإناث ونقص نسب التعذير

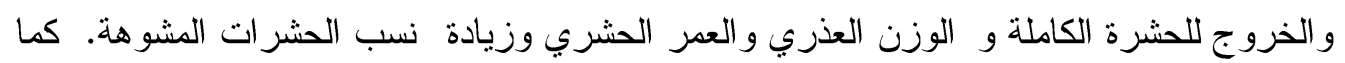

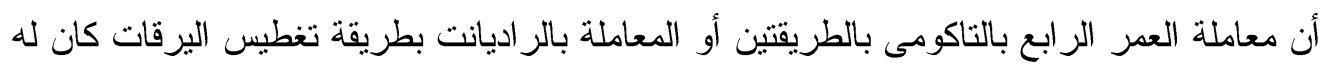

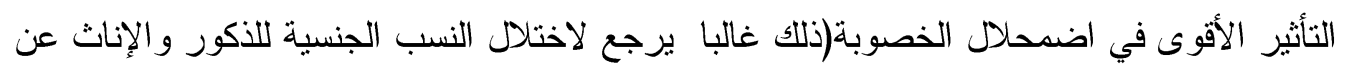

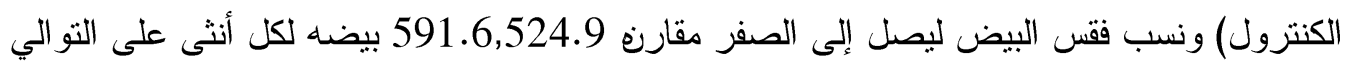
بالكنترول. وبالتالي هذه المو اد تكون فعالة إذا طبقت ضمن بر امج المكافحة المتكاملة لهذه الحشرة و آثزها اقل على البيئة. 